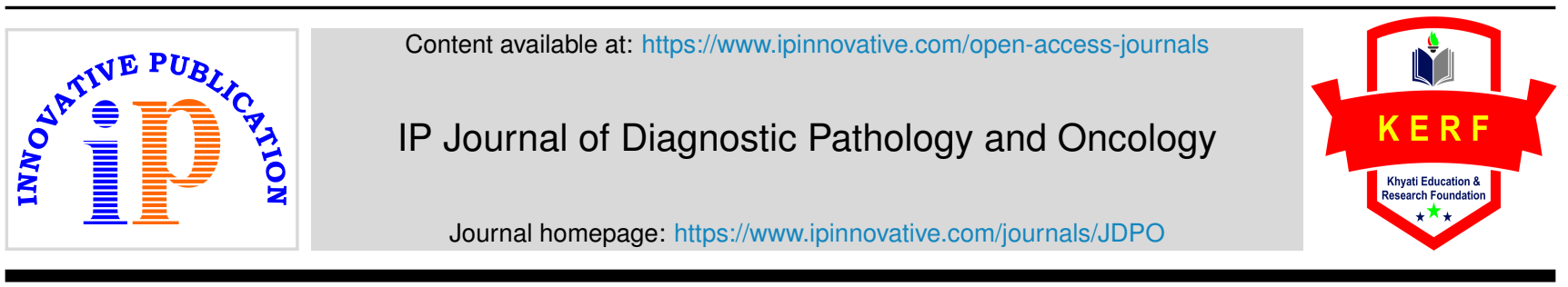

\title{
Editorial
}

\section{Florid plasmacytosis in cases of acute myeloid leukemia: A diagnostic dilemma}

\author{
Iffat Jamal ${ }^{1, *}$ \\ ${ }^{1}$ Dept. of Hematology, Indira Gandhi Institute of Medical Sciences, Patna, Bihar, India
}

\section{A R T I C L E I N F O}

Article history:

Received 25-10-2020

Accepted 02-11-2020

Available online 18-12-2020
(C) This is an open access article distributed under the terms of the Creative Commons Attribution License (https://creativecommons.org/licenses/by/4.0/) which permits unrestricted use, distribution, and reproduction in any medium, provided the original author and source are credited.

\section{Sir,}

The association of acute myeloid leukemia (AML) with plasmacytosis is a known, although rare event. There are very few case reports documenting an increase in the number of plasma cells at the time of AML diagnosis. Paracrine interleukin-6 production by leukemic blast cells is thought to contribute to this associated reactive plasma cell proliferation.

Plasmacytosis is known in acute myeloid leukemia bone marrows undergoing remission after chemotherapy. However plasmacytosis presenting at the time of AML diagnosis is relatively rare. An exuberant proliferation of plasma cells on bone marrow examination masking the exact percentage of blasts can easily be confused with plasma cell dyscrasias.

Reactive plasmacytosis characterized by a diffuse distribution of mature plasma cells in the bone marrow is known to occur in inflammatory conditions (bacterial and viral infections, collagen vascular diseases, granulomatous diseases, rheumatic heart disease), in liver cirrhosis and as a paraneoplastic syndrome in various neoplasms such as Hodgkin's disease, non-Hodgkins lymphomas, carcinomas, ${ }^{1-3}$ and in AML patients undergoing induction chemotherapy. ${ }^{4}$

Cases of AML that have a high plasma cell count can present as diagnostic dilemmas and should always be subjected to further sophisticated investigations

\footnotetext{
* Corresponding author.

E-mail address: iffatjamal111@gmail.com (I. Jamal).
}

before a diagnosis is given based only on morphology. Morphological features suggesting a reactive nature of plasma cells, although not specific, are mature forms of plasma cells, perivascular location of plasma cells and plasmacytic satellitosis (orientation of plasma cells around histiocytes). ${ }^{5}$

Few cases have been reported in the literature where plasmacytosis is seen with AML at the time of diagnosis. ${ }^{5-7}$ In these cases, plasma cells usually do not exceed $10 \%$. However, there are very few cases where the plasma cell count is found to be higher than $20 \%$ in newly diagnosed acute leukemias. In a study by Rosenthal et al., ${ }^{7} 149$ cases of AML were studied at the time of diagnosis, with only two cases showing a plasma cell count of more than $20 \%$.

The etiology of reactive bone marrow plasmacytosis is supposed to be a physiological response to antigenic stimulation. ${ }^{1,2}$ Although mediation by a paracrine growth factor originating from the leukemic cells is possible, the mechanism of this bone marrow plasmacytosis has not yet been addressed. Interleukin (IL)-6 production by the AML blasts may play a pivotal role in the growth of the plasma cells. ${ }^{5}$ For a definitive estimation of the role of IL-6 in AML-associated plasmacytosis, a larger cohort of patients should be analyzed.

\section{References}

1. Hyun BH, Kwa D, Gabaldon H, Ashton JK. Reactive Plasmacytic Lesions of the Bone Marrow. Am J Clin Pathol. 1976;65(6):921-8. doi:10.1093/ajcp/65.6.921. 
2. Liu CT, Dahlke MB. Bone Marrow Findings of Reactive Plasmacytosis. Am J Clin Pathol. 1967;48(6):546-51. doi:10.1093/ajcp/48.6.546.

3. Sivasankaran S, Das KV, Thomas M, Pillai R, Balaram P, Augustin $\mathrm{J}$, et al. Adrenal carcinoma with reactive plasmacytosis. $J$ Assoc Physicians India. 1989;37:237-9.

4. Al-Shughair N, Al-Dawsari G, Gyger M, Mohamed G, Roberts G. Clinical significance of plasmacytosis in the day+14 bone marrow of patients with acute myeloid leukaemia undergoing induction chemotherapy. $J$ Clin Pathol. 2006;60(5):520-3. doi:10.1136/jcp.2005.032870.

5. Wulf GG, Jahns-Streubel G, Hemmerlein B, Bonnekessen K, Wörmann B, Hiddemann W, et al. Plasmacytosis in acute myeloid leukemia: two cases of plasmacytosis and increased IL- 6 production in the AML blast

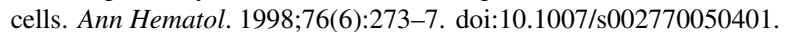

6. Gavarotti P, Boccadoro M, Redoglia V, Golzio F, Pileri A. Reactive plasmacytosis: Case report and review of the literature. Acta Haematol. 1985;73:108-18.

7. Rosenthal NS, Farhi DC. Reactive plasmacytosis and lymphocytosis in acute myeloid leukemia. Hematol Pathol. 1994;8:43-51.

\section{Author biography}

Iffat Jamal, Assistant Professor

Cite this article: Jamal I. Florid plasmacytosis in cases of acute myeloid leukemia: A diagnostic dilemma. IP J Diagn Pathol Oncol 2020;5(4):351-352. 